Farkas, Tamás . "A Selected and Annotated Bibliography for the Research of Official Surname Changes in Hungary." AHEA: E-journal of the American Hungarian Educators Association, Volume 5 (2012): http://ahea.net/ejournal/volume-5-2012

\title{
A Selected and Annotated Bibliography for the Research of Official Surname Changes in Hungary"
}

Tamás Farkas, Eötvös Loránd University, Budapest

The bibliography presented here contains only those publications in the field which are possible to study without knowledge of the Hungarian language, i.e. which were written in English or other foreign languages, or which simply publish a database of the name changes. The annotations are based on the texts of the publications and the abstracts (if they were available). Naturally, there are also many additional contemporary sources and scholarly publications available in the field in Hungarian, many (lately the majority) include an English abstract. For a more complete list of the literature on the topic to 2009, see:

Farkas, Tamás. 2009. “A magyar családnév-változtatások szakirodalmának válogatott bibliográfiája (1872-2009)." [Selected Bibliography of the Research of Surname Changes in Hungary (1872-2009).] In Tamás Farkas \& István Kozma, eds. A családnévváltoztatások történetei időben, térben, társadalomban. Budapest: Gondolat Kiadó \& Magyar Nyelvtudományi Társaság: 397-404. (See another version at http://nevvaltoztatas.elte.hu.)

For books (two monographs and one collection of studies) written about surname changes in Hungary, see the review of Mariann Sliz in this issue. http://ahea.net/e-journal/volume-5-2012

\section{Sources from the History of Official Surname Changes in Hungary}

[Szent-Iványi, Zoltán.] 1895/2011. Századunk névváltoztatásai. Helytartósági és miniszteri engedélylyel megváltoztatott nevek gyüjteménye 1800-1893. [Name Changes in the Present Century. A Collection of Name Changes Authorized by the Proconsulate and the Cabinet Minister.] Budapest: Hornyánszky Viktor. In reprint: Budapest: Históriaantik Könyvkiadó. Pp 254. (See also: http://mek.oszk.hu/07400/07431.) This book is a collection, and is the best source of the official surname changes (authorized by the Proconsulate and Ministry of Internal Affairs) between 1800 and 1893 in Hungary. It contains the most important data of the cases: the new and the original surname; the first name, the place of dwelling and (regularly) the occupation of the applicant; the first names of his (her) children; the year of the change-of-name; the number of the authorization. The cases are listed in the alphabetical order of the adopted surnames. The book has an introduction (in Hungarian) about the history, the regulation and the importance of the name Magyarization.

Telkes, Simon. 1977. How to Become a Hungarian. The Artificial Reproduction of a People. Roma: Edizioni Europa. Pp IV+92. The core of the publication is Hogy magyarositsuk a vezetékneveket? / A Guide to the Magyarisation of Surnames (pp 45-81), a brochure originally published in 1898 ( $2^{\text {nd }}$ edition, it had four editions between 1897

\footnotetext{
* Prepared with the support of the Bolyai Research Fellowship of the Hungarian Academy of Sciences.
} 
Farkas, Tamás . "A Selected and Annotated Bibliography for the Research of Official Surname Changes in Hungary." AHEA: E-journal of the American Hungarian Educators Association, Volume 5 (2012): http://ahea.net/ejournal/volume-5-2012

and 1906) in Hungary, written by the most zealous and self-appointed promoter of Name Magyarizations, Simon Telkes (earlier Rubin). It contains the following chapters: The Magyar Name, How to Magyarise surnames, Formalities for the Magyarisation of names, "Recommended" Magyar surnames, and Historical documentation on the Magyarisation of names. The original brochure is published both in English and in Hungarian here, but accompanied by some later historical-propagandistic texts (e.g. "Transylvania, the absurd dream of the Hungarians"), from different authors and viewpoints. A publication of Dragan European Foundation, also in a French version (see below).

Telkes, Simon. 1977. Les faux hongrois: la multiplication artificielle d'un peuple. [The False Hungarian. The Artificial Reproduction of a People.] Milano: Editrice Nagard. Pp $\mathrm{V}+81$. This is the French version of the publication listed above.

Tressel, Anton n. d. Das Portal der Ungarndeutschen. http://www.ungarndeutsche.de . This portal contains lists of Magyarised foreign (first of all: German) surnames, e.g. in different Hungarian settlements, based on various sources (first of all: individual informants). The lists of surname pairs are published without the details of the specific cases. See also the similar (but shorter) lists of non-Hungarian (German)/Magyarised surname pairs (and vice versa) in the book by the same the author: Ungarische Familiennamen im deutschen Sprachgebiet. [Hungarian Surnames in the German Language Area.] Saarbrücken: published by the author, 2002: 26-43.)

\section{Scholarly Papers from the Research of the History of Official Surname Changes in Hungary}

Dúró, Erzsébet. 2002. "Naamsverandering in het licht van de Hongaarse geschiedenis." [Name Change in Hungarian History.] In Júlia Albert-Balázsi \& A. Agnes Sneller, ed. Paralellen. Károli-studies II. Studierichting Nederlandse taal en cultuur. Budapest: Károli Gáspár Reformatorische Universiteit: 127-148. This paper overviews the history of official surname changes in their social and historical context, presenting the characteristics of its different periods (before 1787, 1787-1814, 1814-1881, 1881-1920, 1920-1945, 1945-1948, 1948-1990), marked by the events of the pertaining legislation as well as the historical events. It also studies briefly the one-time brochures that propagated the name Magyarization in its Golden Age. It presents the typological surname innovations of the process, the naming fashions of the history of surname changes, and the ways in which the new surnames were chosen.

Farkas, Tamás. 2008. "Surname Changes in Hungary: Researches and Their Onomastic Conclusions." In Maria Giovanna Arcamone, Davide de Camilli \& Bruno Porcelli, eds. Proceedings. 22nd International Congress of Onomastic Sciences. Pisa (Italy), 28.84.9.2005. Pisa: Edizioni Ets: II, 343-350. This paper investigates the reasons for the differences between the stock of surnames that arose naturally in the community and the stock of surnames that were created artificially later via a legal procedure of surname changes. These differences are determined by the circumstances and ways of their 
Farkas, Tamás . "A Selected and Annotated Bibliography for the Research of Official Surname Changes in Hungary." AHEA: E-journal of the American Hungarian Educators Association, Volume 5 (2012): http://ahea.net/ejournal/volume-5-2012

emergence: When were these names born? Who gives the name and to whom? Why is that name born? On what basis is the surname chosen? From what material (set of linguistic elements) and in what way is the surname formed? Besides these aspects, the most typical types of neologisms are examined here by examples and comments.

Farkas, Tamás. 2008. “The Research of Official Family Name Changes in Hungary.” In István Hoffmann \& Valéria Tóth, eds. Onomastica Uralica 7: 87-102. DebrecenHelsinki. (See also: http://mek.oszk.hu/06800/06838.) This paper presents the history, the interdisciplinary character and the secondary literature of the research in the field of official surname changes in Hungary, followed by an account of the work and the plans of an interdisciplinary research group. It presents a theoretical framework for the appropriate study of the complex phenomenon of surname changes. It gives an account of the examination of its primary sources and the building of a database, and also overviews the partial and case studies on different aspects of the topic that had been made in the previous years in the field.

Farkas, Tamás. 2009. "Surnames of Foreign Origin in a Language Contact Situation. The Reasons and Ways of Their Changes and Their Influence on the Surname Stock in Hungary." In Wolfgang Ahrens, Sheila Embleton \& André Lapierre, eds. Names in Multi-Lingual, Multi-Cultural and Multi-Ethnic Contact. Proceedings of the 23rd International Congress of Onomastic Sciences. August 17-22, 2008, York University, Toronto, Canada. Toronto: York University: 365-374. (See also: http://pi.library.yorku.ca/dspace/handle/10315/3967.) The paper overviews the development of the surname stock of different minorities in historical Hungary, including the official influence in some cases. It studies the connotative value of surnames of a given ethnic character in a different linguistic and cultural context, and the process of the assimilation of these names and their bearers. It analyzes the reasons and the ways of the spontaneous and the official surname changes, and how the linguistic characteristics of the original foreign surnames and the existing Hungarian surname stock both could influence the formation of the new names, as well as the structure of the surname system in Hungary.

Farkas, Tamás. 2009. “Jewish Surname Changes in Hungary $\left(19^{\text {th }}-20^{\text {th }}\right.$ century).” In Wolfgang Ahrens, Sheila Embleton \& André Lapierre, eds. Names in Multi-Lingual, Multi-Cultural and Multi-Ethnic Contact. Proceedings of the 23rd International Congress of Onomastic Sciences. August 17-22, 2008, York University, Toronto, Canada. Toronto: York University: 375-384. (See also: http://pi.library.yorku.ca/dspace/handle/10315/3968.) This is an earlier version of Farkas, Tamás. 2012 (see below).

Farkas, Tamás. 2012. “Jewish Name Magyarization in Hungary.” AHEA 5. http://ahea.net/e-journal/volume-5-2012. This paper applies different sources to investigate the social, historical, cultural and ideological context and the characteristics of the surname changes of the Jews in Hungary. It analyzes the names as ethnic symbols, and the reasons that made surname changes so widespread among Jews all over the 
Farkas, Tamás . "A Selected and Annotated Bibliography for the Research of Official Surname Changes in Hungary." AHEA: E-journal of the American Hungarian Educators Association, Volume 5 (2012): http://ahea.net/ejournal/volume-5-2012

world. It presents the assimilation process of Jewish persons and their personal names in general, and the history of the Jewish Name Magyarization in Hungary. The characteristic features of the surnames chosen and their typical motivations are also analyzed, in comparison with those of the non-Jews in the country.

Forgács, Krisztina. 1990. "Hungarianization of Jewish Surnames.” In Eeva Maria Närhi, ed. Proceedings of the XVIIth ICOS, Helsinki, August 13-l8, 1990. Helsinki: The University of Helsinki and the Finnish Research Centre for Domestic Language: 1, 322328. This study is based on a survey of the original petitions by Hungarian Jews for a change of name between 1869 and 1945 in Hungary. It analyzes the etymological types of the original names (mostly of German origin), and with many examples, a detailed semantic and morphological typology of the adopted Hungarian surnames, as well as the ways of changing the surname (mostly by preserving the initials, less frequently on a semantic basis). It also lists the most frequent old surname/new surname pairs, and makes some remarks on the changes of the length of surnames in these changes.

Frojimovics, Kinga. 2003. "Jewish Naming Customs in Hungary from the Turn of the Twentieth Century until the Holocaust." The 23rd International Conference on Jewish Geneology. July 20-25, 2003, Washington DC. http://www.jewishgen.org/Hungary/2003nameskinga.html. This paper describes the different naming customs of the Neologous and the Orthodox Jewry in Hungary, based on the names in the registers of births of four Jewish communities in 1890-1910 and 1920-1940. It identifies a period of assimilation promoted by the liberal Hungarian political elite, and a period of a more nationalist, exclusion-oriented policy towards minorities. A simultaneous examination of the Jewish first, family, and Hebrew names are to be found here. While the first and family names inform us about the relationship between Jews and the surrounding society, the Hebrew names show the different relationship of the Jews belonging to the two major religious trends to the Jewish traditions.

Juhász, Dezső. 2007. "Nationaler Charakter, Identität und Namensänderung in Ungarn im 19. Jahrhundert." [National Character, Identity and Name Change in Hungary in the $19^{\text {th }}$ Century.] In Rogier Blokland \& Cornelius Hasselblatt, eds. Language and Identity in the Finno-Ugric World. Proceedings of the Fourth International Symposium on FinnoUgric Languages at the University of Groningen. May 17-19, 2006. Studia Fenno-Ugrica Groningana 4. Maastricht: Shaker Publishing BV: 164-175. This paper, on the basis of literature and historical sources, studies (with many examples) how national ideology and an idealized national character can be seen in the semantics of the new surnames adopted in the history of surname changes in Hungary. It emphasizes that the aim of these changes was to adopt a more 'beautiful', a more 'pleasant-sounding' name, especially to change the foreign surnames to be a '(more) Hungarian' one, which is the connection between the assimilation of names and the changes of national identity in the $19^{\text {th }}$ century. The paper also informs us about the formation of an interdisciplinary research team for the study of the history of surname changes in Hungary. 
Farkas, Tamás . "A Selected and Annotated Bibliography for the Research of Official Surname Changes in Hungary." AHEA: E-journal of the American Hungarian Educators Association, Volume 5 (2012): http://ahea.net/ejournal/volume-5-2012

Karády, Viktor. 1999. “Aspects of Unequal Assimilation in Liberal Hungary. Social Geography of the Movement to Magyarise Alien Surnames before 1918." In Eszter Andor, Andrea Peto \& István György Tóth, eds. CEU History Department Yearbook 1997-8. Budapest: Central European University: 49-68. This study identifies some major patterns related to the distribution of surname changes in social space in Hungary between 1848-49 and 1918. It briefly analyzes the background of Name Magyarization as a nation-building process, a means of symbolic assimilation and social integration, and overviews the historical growth of the movement. The study focuses on the ethnic and denominational, the residential-geographical and the social class specific features and tendencies of the process, with numerical data in tables and their social-historical analyses. Special attention is given to the differences between the Jews and Christians changing their names.

Kontra, Miklós. 1990. "Changing Names: Onomastic Remarks on Hungarian Americans." Journal of English Linguistics 23: 114-122. This paper summarizes the results of interviews of Hungarian-Americans and an examination of the most frequent Hungarian surnames of the telephone directory in South Bend, Indiana. It studies the ways of changes of Hungarian surnames in the USA: the changes in orthography, in pronunciation, the translation of the name and the changes for a completely different surname. The typical motivations for and the attitudes towards these changes are also presented here, based upon the personal experiences of the informants. Further analyses are directed at the first names and middle names of the Hungarian-Americans.

Kőhegyi, Mihály; Merk, Zsuzsa. 1995/1996. Die Namensänderungen in Baja 18951945. [The Name Changes in Baja, 1895-1945.] Südostdeutsches Archiv 38/39: 71-96. This paper discusses the surname changes in the Hungarian town of Baja, home of different national minorities (Serbs, Slovaks, Germans, Jews), from 1895 to 1945, in the context of the historical and ethnic features, according also to the linguistic and onomastic aspects. The study is based on a complete survey of the official registers of birth of the era, and presents a detailed and exemplary analysis of the history, the background and the characteristics of surname changes in the town, with a special emphasis on the local features and events of the movement.

Nogrady, Michael. 1990. "Treatment of Hungarian Names in Canada." In Jean-Claude Boulanger, ed. Proper Names at the Crossroads of the Humanities and Social Sciences. Proceedings of the XVIth International Congress of Onomastic Sciences. Québec, Université Laval. 16-22 August 1987. Québec: Université Laval: 433-440. This paper studies the ways of transformation of personal names of Hungarian immigrants to Canada. In the case of surnames, the typical changes are the changes in pronunciation and the changes in orthography (preserving the original written form or the adequate phonetic rendition), but the cases of shortening, translating or completely changing the surname are also known. The ways of treatment of Hungarian given names are also studied in the paper. The conclusion is that names from a non-cognate language cannot retain their original forms in a society where an official language is neither phonetically nor orthographically equipped to sustain the non-cognate forms. 
Farkas, Tamás . "A Selected and Annotated Bibliography for the Research of Official Surname Changes in Hungary." AHEA: E-journal of the American Hungarian Educators Association, Volume 5 (2012): http://ahea.net/ejournal/volume-5-2012

Maitz, Péter. 2008. "Der Familienname als Ausschluss- und Machtinstrument. Eine kritisch-diskursanalytische Fallstudie." [The Family Name as a Means of Exclusion and Power. A Case Study by Critical Discourse Analysis.] In Nicole Eller, Stefan Hackl \& Marek L'upták, eds. Namen und ihr Konfliktpotential im europäischen Kontext. Regensburger Symposium, 11. bis 13. April 2007. Regensburg: Edition Vulpes: 187-217. This paper gives the critical discourse analysis of the propaganda of Magyarization of surnames, which in the second half of the long $19^{\text {th }}$ century aimed at spreading and executing a so-called "national name ideology". The analysis primarily explores those discourse strategies (ideological contents and their linguistic representations) by which people bearing surnames of non-Hungarian origin were convinced to adopt the idea and to Magyarise their surnames. In the background of the phenomenon the dominant language ideology of the era, linguistic nationalism is identified. The study is based upon contemporary sources prepared mostly for propagandistic reasons.

Maitz, Péter \& Farkas, Tamás. 2008. “Der Familienname als Nationalsymbol. Über den Untergang deutscher Familiennamen im Ungarn des 19. Jahrhunderts." [The Family Name as a National Symbol. The Decline of German Family Names in Hungary in the $19^{\text {th }}$ Century.] Zeitschrift für germanistische Linguistik 36: 163-196. This study is based on the fact that the Magyarization of surnames mostly affected people of German or Jewish origin bearing German family names. After giving a numerical description of the process, the sociolinguistic background of German surname use is examined. The paper analyses the semantic structure of the surname as well as its use as the tool of language ideology, namely linguistic nationalism. The movement of name Magyarization is identified as a behavioral pattern of middle-class people ready to accept social mobility and willing to take part in assimilation. Finally, the aesthetic, functional and linguistic principles of surname changes are discussed in the paper.

Megyeri-Pálffi, Zoltán. 2007. “The History of Regulation of Changing Names in Hungary.” In Analele Universitatii Din Oradea, Fascicula Drept Anul XV: 121-130. Oradea: Editura Universitátu Din Oradea. This paper presents the different types of personal name changes in Hungary, according to name types and legal categories. It overviews their regulation from the $19^{\text {th }}$ century to date, putting the accent on the development of the history of law. It examines the most important changes in this regulation, analyzing in detail the last regulation in 2002 and the present situation from the aspects of jurisprudence. The attention first of all is turned to the questions of surname changes, but the regulation of first name changes are also treated.

Szávai, Ferenc. 2007. "Die Rolle der Ungarischen Akademie der Wissenschaften (MTA) bei der deutschen Namenmagyarisierung in der Zwischenkriegszeit." [The Role of the Hungarian Academy of Sciences in the German Name Magyarization in the Interwar Period.] In Andreas Bock, Nelu Bradean-Ebinger, eds. Akten der Historikerkonferenz zum Volksbund der Deutschen in Ungarn (1938-45). Budapest, am 24.02.2007. Sonntagsblatt - Bücherei Nr. 4. Budapest: Jakob Bleyer Gemeinschaft e.V.: 18-42. This paper presents the occasional advisory work of the associates of the 
Farkas, Tamás . "A Selected and Annotated Bibliography for the Research of Official Surname Changes in Hungary." AHEA: E-journal of the American Hungarian Educators Association, Volume 5 (2012): http://ahea.net/ejournal/volume-5-2012

Hungarian Academy of Sciences in the surname change processes of the interwar period in Hungary, especially the practice of linguist János Melich, based on archival sources. It overviews the types as well as the distribution of the academic evaluations of 193 cases initiating a change of a surname of supposedly German origin, produced between 1933 and 1945 in the country. Some of the cases are presented in detail. In an appendix (pp 2940) the list of these surnames and their evaluations are also presented.

Szilágyi-Kósa, Anikó. 2009. “Zur Geschichte und den sprachlichen Strategien eines massenhaften Namenwechsels (Kischludt/Kislöd, 1868).“ [On the History and the Linguistic Strategies of a Mass Name Change (Kislőd, 1868).] Studia Germanica Universitatis Vesprimiensis 13: 167-180. This paper studies a peculiar example of a mass surname change in 1868 in the settlement of Kislöd, where almost all inhabitants of German mother tongue and ethnicity changed their surnames to Hungarian ones, a process that was presumably initiated and directed by the parish priest (also of German origin). The paper presents the process of the name changes, where the exceptionally high rate of the translation of the original names resulted in a stock of surnames revealing their artificiality and also the differences between the systems of Hungarian and German surnames. The complete name corpus of these changes is also published in the paper.

Vörös, Ferenc. 2010. "Name Change, Name Alteration, Name Restoration and Minority Name Usage / Névváltozás, névváltoztatás, névhelyreállítás és kisebbségi nyelvhasználat.” Szombathely: Savaria University Press. Pp 49. This study, published in a bilingual publication, deals with the different types and terminological problems of name changes. The introduction discusses the principle of name stability contrasting the historical changes in the Carpathian Basin. The author studies the phenomenon of linguistic borrowing, the integration of names, the changes of names, and systematically defines the pertaining technical terms. Two new technical terms (i.e. name reconstruction serving assimilative and re-assimilative purposes) are introduced, illustrated mainly by (Czecho)Slovakian examples. In the conclusion of the paper the demonstrative model presents the reconsidered system of concepts relating to name changes.

Weidlein, Johann. 1967. "Zur Geschichte der Namensmadjarisierungen.” [To the History of Name Magyarization.] Südostdeutsches Archiv 10: 177-192. This paper provides an overview of the history of Name Magyarization from the beginning of the $19^{\text {th }}$ century until 1945 in Hungary, paying special attention to the question of surname changes of the German minority in the country. It presents the political-ideological context and background of surname changes, based on contemporary sources (official documents, articles of journals, propagandistic, personal and scholarly writings), many of which are also cited here. It focuses on the historic processes and minority matters, but also presents the most frequently adopted surnames in the $19^{\text {th }}$ century. 